\title{
ACTIVE HUMAN CYTOMEGALOVIRUS INFECTION AND GLYCOPROTEIN B GENOTYPES IN BRAZILIAN PEDIATRIC RENAL OR HEMATOPOIETIC STEM CELL TRANSPLANTATION PATIENTS
}

\author{
Débora de Campos Dieamant ${ }^{1}$, Sandra Helena Alves Bonon ${ }^{1}$, Liliane Cury Prates ${ }^{2}$, Vera Maria Santoro Belangelo ${ }^{2}$, Erika \\ R. Pontes ${ }^{3}$, Sandra Cecília Botelho Costa ${ }^{1^{*}}$
}

\author{
${ }^{1}$ Departamento de Clínica Médica, Faculdade de Ciências Médicas, Universidade Estadual de Campinas, Campinas, SP, Brasil; \\ ${ }^{2}$ Departamento de Nefrologia Pediátrica, Faculdade de Ciências Médicas, Universidade Estadual de Campinas, Campinas, SP, \\ Brasil; ${ }^{3}$ Centro Infantil Boldrini, Campinas, SP, Brasil.
}

Submitted: January 28, 2009; Returned to authors for corrections: April 09, 2009; Approved: July 24, 2009.

\begin{abstract}
A prospective analysis of active Human Cytomegalovirus infection (HCMV) was conducted on 33 pediatric renal or hematopoietic stem cell post-transplant patients. The HCMV-DNA positive samples were evaluated for the prevalence of different $\mathrm{gB}$ subtypes and their subsequent correlation with clinical signs. The surveillance of HCMV active infection was based on the monitoring of antigenemia (AGM) and on a nested polymerase chain reaction (N-PCR) for the detection of HCMV in the patients studied. Using restriction analysis of the $\mathrm{gB}$ gene sequence by PCR-RFLP (Restriction Fragment Length Polymorphism), different HCMV strains could be detected and classified in at least four HCMV genotypes. Thirty-three pediatric recipients of renal or bone marrow transplantation were monitored. Twenty out of thirty-three $(60.6 \%)$ patients demonstrated active HCMV infection. gB1 and gB2 genotypes were more frequent in this population. In this study, we observed that $\mathrm{gB} 2 \mathrm{had}$ correlation with reactivation of HCMV infection and that patients with mixture of genotypes did not show any symptoms of HCMV disease. Future studies has been made to confirm this.
\end{abstract}

Key words: cytomegalovirus, pediatric transplantation, gB genotypes, PCR, antigenemia

\section{INTRODUCTION}

Human cytomegalovirus (HCMV) remains the most important cause of serious viral infections in pediatric transplant recipients (23). In these patients, early diagnosis of active HCMV infection is important, since the development of HCMV disease may be prevented (17). Ganciclovir has been established as an effective treatment agent for infection by HCMV $(15,38)$. Primary HCMV infection occurs in patients that were HCMV-seronegative prior to acquiring HCMV. Recurrent infection occurs in patients that have previously documented infection with no virus detected for at least 4 weeks during active surveillance; such infection may result from reactivation of latent virus or reinfection. HCMV disease can occur from infection acquired post-operatively in the transplanted organ or from reactivation of latent infection with symptoms and/or tissue invasion (25). The risk is highest within 2 months after transplantation. Several risk factors for 
HCMV disease have been identified and include HCMVpositive donor, HCMV-negative recipient, lack of antiviral prophylaxis, and receipt of cadaveric kidney or type of bone marrow transplant. Intense immunosuppression has also been implicated. Detection of HCMV DNA by qualitative PCR and of protein pp65 by antigenemia, together, are good methods for the detection of active infection. The HCMV antigenemia assay is a rapid and semi-quantitative method that is widely used us a guideline for starting treatment therapy with ganciclovir (14). Genetic variability of genes among different virus strains may influence clinical manifestations of HCMV infections (19, 37). Such variability, particularly in the glycoprotein B $(\mathrm{gB})$ gene of the viral envelope, appears to be of clinical relevance because these proteins are assumed to play an essential role in the induction of immune response and in viral entry into host cells, and have been considered as a potential marker for viral virulence $(4,6,24)$. Since differences among gB strains may influence pathogenesis $(19,33)$, we examined the frequency distribution of $\mathrm{gB}$, by monitoring active HCMV infection in pediatric patients recipients of renal and bone marrow transplants using HCMV-DNA detection and the antigenemia test. The subtype results were correlated with the clinical findings.

\section{MATERIALS AND METHODS}

Thirty-three patients (19 recipients of renal and 14 recipients of bone marrow transplant) were monitored prospectively for active HCMV infection from August 2004 to December 2005 using AGM and N-PCR. The characteristics of the groups studied were described in Table 1 . The patients were followed from day 0 until day 150 after the transplant. Blood was colleted weekly for AGM and N-PCR. The protocol was designed in accordance with the requirements for research involving human subjects in Brazil and approved by the Institutional Ethics Committee. The sample of the patients who were positive for the nested-PCR $(10,35)$ were selected for genotyping.

Table 1. Characteristics of the groups studied

\begin{tabular}{|c|c|c|c|c|}
\hline Characteristic & \multicolumn{2}{|c|}{ BMT $(n=14)$} & \multicolumn{2}{|c|}{ Renal $(n=19)$} \\
\hline Age-median in years (range) & \multicolumn{2}{|c|}{$10(2-18)$} & \multicolumn{2}{|c|}{$11(5-18)$} \\
\hline Sex -male/female & \multicolumn{2}{|c|}{$10 / 4$} & \multicolumn{2}{|c|}{$10 / 9$} \\
\hline \multirow[t]{3}{*}{ Underlying disease-n (\%) } & AML & $8(57)$ & CNS & $16(84.2)$ \\
\hline & NHL & $3(21.4)$ & $\mathrm{CHG}$ & $2(10.5)$ \\
\hline & SAA & $3(21.4)$ & $\mathrm{UC}$ & $1(5.3)$ \\
\hline \multirow[t]{2}{*}{ Donor type } & Allogeneic & $14(60.9)$ & Cadaver & $15(78.9)$ \\
\hline & & & $\begin{array}{l}\text { Living } \\
\text { related }\end{array}$ & $4(21.1)$ \\
\hline \multicolumn{5}{|c|}{ Pretransplant HCMV serostatus - n (\%) } \\
\hline IgG-HCMV- R-/D+ & \multicolumn{2}{|c|}{ - } & \multicolumn{2}{|c|}{$2(10.5)$} \\
\hline IgG-HCMV- R+/D+ & \multicolumn{2}{|c|}{$14(100)$} & \multicolumn{2}{|c|}{$17(89.5)$} \\
\hline \multicolumn{5}{|l|}{ Conditioning regimen $-\mathrm{n}(\%)$} \\
\hline $\mathrm{Bu}+\mathrm{Cy}$ & \multicolumn{2}{|c|}{$14(100)$} & \multicolumn{2}{|c|}{-} \\
\hline Prograf/Micofenolat/Pred+Simulet & \multicolumn{2}{|c|}{ - } & \multicolumn{2}{|c|}{$19(100)$} \\
\hline HCMV prophylaxis (Ganciclovir) & \multicolumn{2}{|c|}{-} & \multicolumn{2}{|c|}{2 (IgG-) } \\
\hline
\end{tabular}

BMT-Bone Marrow Transplantation; AML-Acute myelogenous leukemia; NHL-Non-Hodgkin lymphoma; SAA-severe anemia aplastic anemia; CNC-Congenital nephrotic syndrome; CHG-Chronic and hereditary glomerulonephritis; UC-Unknown cause; R-/D+-negative recipient with positive donor IgG-HCMV; R+/D+-positive recipient and donor for IgG-HCMV; Bu-busulfan; Cy-cyclosphosphamide; Pred-prednosone. 


\section{HCMV antigenemia (AGM) assay}

The antigenemia assay was performed at least once a week after engraftment, as previously described (34), with some modifications $(5,18,29)$. Briefly, EDTA-treated blood samples were fractionated by dextran sedimentation followed by erythrocyte lysis. The granulocytes were then centrifuged to prepare Cytospin slides ( $3 \times 10^{5}$ granulocytes per slide). The slides were air-dried and fixed with formaldehyde, then immunostained with monoclonal antibodies, C10 and C11 (Clonab HCMV; Biotest, Dreieich, Germany), and reacted with peroxidase-labeled anti-mouse cojugate (HRP, Biotest, Dreieich, Germany). The test was carried out in duplicate.

\section{Nested polymerase chain reaction (N-PCR)}

HCMV DNA in blood specimens was detected by nested PCR, using the primers described by Demmler et al (11) and Shibata et al (31). Briefly, leukocytes remaining from the HCMV antigenemia assay were lysed and the DNA was precipitated. The primers were selected from the MIE region of HCMV-AD169. The size of the PCR amplification products was 159 base pairs. The same protocol was used to amplify the human $\beta$-globin gene sequence to guarantee the quality of the extracted DNA.

\section{Treatment of active HCMV infection}

Patients with proven active HCMV infection received ganciclovir $(5 \mathrm{mg} / \mathrm{Kg}$, i.v.) twice a day for 7 days, followed by a maintenance dose of $5 \mathrm{mg} / \mathrm{Kg} /$ day, i.v., 3 times a week. Treatment was restarted if active HCMV infection remained detectable. Treatment of HCMV disease was treated with ganciclovir ( $5 \mathrm{mg} / \mathrm{Kg}$, i.v.), twice a day for 21 days, followed by a maintenance dose of $5 \mathrm{mg} / \mathrm{Kg} /$ day, i.v., three times a week for 4 weeks.

\section{Definitions}

Active HCMV infection was defined based on one or both of the following criteria: (1) one or more positive cells in the AGM assay, and (2) two or more consecutive positive N-PCR results. HCMV disease was defined as HCMV infection with specific signs or symptoms consistent with presumed or proven disease. A presumed case of HCMV disease was defined as demonstration of HCMV infection and fever of greater than $38.8^{\circ} \mathrm{C}$ for at least 2 days, and one of the following: atypical lymphocytosis; white blood cell count less than $4,000 / \mathrm{mm}^{3}$; or platelet count less than $100,000 / \mathrm{mm}^{3}$, without any other infection or non-infectious cause identified after investigations that included assays for EBV infection and other etiologies for post-transplant infections (25). Recurrence of HCMV infection or Disease was defined as active HCMV infection or HCMV disease occurring after negative N-PCR and/or AGM assays, following treatment of the initial episode of infection or disease. Late active HCMV infections and diseases were defined as those occurring more than 100 days after transplant (5).

\section{Amplification of the gB gene by nested PCR}

The oligonucleotide primers used for PCR amplification were chosen in a region of high sequence variability in the HCMV gB gene, as previously published $(9,35)$ and were synthetized commercially (Invitrogen, Life Technologies, SP, Brazil). Primers are listed in Table 2. The first and the second rounds of amplification were carried out in a total volume of $50 \mu \mathrm{l}$ using $200 \mathrm{ng}$ DNA extract $\left(1^{\text {st }}\right)$ and $1 \mu \mathrm{l}$ PCR product $\left(2^{\text {nd }}\right)$ and $49 \mu \mathrm{l}$ PCR mix (10 mM Tris $\mathrm{pH} 8.3,50 \mathrm{mM} \mathrm{KCl}, 2$ $\mathrm{mM} \mathrm{MgCl} 2,200 \mu \mathrm{M}$ of each dNTPs, $1.25 \mathrm{U}$ of recombinant Taq DNA polymerase and $0.4 \mu \mathrm{M}$ of each primer (Invitrogen, Life Technologies). After amplification, $5 \mu$ of the amplified product were electrophoresed on $2 \%$ agarose gel (Gibco-BRL, Gand Island, NY) containing ethidium bromide, and the gel was photographed under UV illumination. The AD169 strain was used as a positive control; an uninfected DNA sample or water was used as a negative control.

\section{RFLP analysis}

Approximately $10 \mu \mathrm{l}$ of nested PCR product were digested at $37^{\circ} \mathrm{C}$ overnight, using $1 \mathrm{U}$ of the restriction enzymes, Rsa I and Hinf I (Gibco-BRL). Sequences were analyzed on a $2 \%$ agarose 1000 gel (Gibco-BRL). The four types of $\mathrm{gB}$ were distinguished by their different patterns of fragment lengths, as described (9). 
Table 2. gB Primers sequences and PCR product sizes

\begin{tabular}{|c|c|c|c|}
\hline \multirow[t]{2}{*}{ Round } & \multicolumn{2}{|c|}{ Primer sequences } & \multirow[t]{2}{*}{ PCR product } \\
\hline & Forward & Reverse & \\
\hline \multirow[t]{2}{*}{$1^{\mathrm{st}}$} & gB 1319 & gB 1659 & $\sim 355 \mathrm{bp}$ \\
\hline & TGGAACTGGAACGTTTGGC (22) & GCACCTTGACGCTGGTTTGG (9) & \\
\hline \multirow[t]{2}{*}{$2^{\mathrm{st}}$} & gB 1319 & gB 1604 & $\sim 299-305 \mathrm{bp}$ \\
\hline & TGGAACTGGAACGTTTGGC (22) & GAAACGCGCGGCAATCGG (22) & \\
\hline
\end{tabular}

Note: All sequences are based on the AD 169 sequence (GenBank Accession No. X04606).

\section{RESULTS}

\section{Active HCMV infection after transplantation}

Antigen pp65-HCMV and HCMV-DNA were successfully detected by AGM and N-PCR, respectively. Table 3 shows the incidence of active HCMV infection detected by AGM and/or N-PCR. Twenty out of thirty-three patients $(60.6 \%)$ had active HCMV infection during monitoring, in a median of 41 days after the transplant. Five of these patients were BMT recipients $(35.7 \%)$ with a median of 41 days after the transplant, and thirteen were renal recipients $(79 \%)$ with a median of 42 days after the transplant. Two renal transplant patients were HCMVIgG negative prior to the transplant and had primary HCMV infection because the organ was from an HCMV-IgG positive donor. Both of these patients had active HCMV infection and presumptive disease, even though both had received ganciclovir prophylaxis after the transplant. Table 4 shows the correlation between antigenemia and N-PCR positive. Four patients had active HCMV infection detected by N-PCR and no detect by AGM. These cases did'nt show HCMV disease.

\section{Recurrence of active HCMV Infection}

Recurrence of active HCMV infection occurred in five out of twenty patients with previous active HCMV infection, in a median of 128 days after the transplant. These results are summarized in Table 3.

Table 3. Incidence of active HCMV infection

\begin{tabular}{lccc}
\hline & BMT - n(\%) & Renal - n(\%) & Total - n (\%) \\
& $\mathbf{N = 1 4}$ & $\mathbf{N = 1 9}$ & $\mathbf{N = 3 3}$ \\
\hline Active HCMV infection Patients, n (\%) & $5(35.7)$ & $15(79)$ & $20(60.6)$ \\
median time-days (range) & $41(13-98)$ & $42(16-110)$ & $41(13-98)$ \\
2 or more positive consecutive results by N-PCR (\%) & $5(35.7)$ & $15(79)$ & $20(60.6)$ \\
median time-days (range) & $37(13-98)$ & $40(16-110)$ & $41(13-110)$ \\
1 or more positive cells by AGM (\%) & $3(21.4)$ & $13(68.4)$ & $16(48.5)$ \\
(range positive cells) & $(1-15)$ & $(1-80)$ & $(1-80)$ \\
median time-days (range) & $45(13-98)$ & $44(22-98)$ & $41(13-110)$ \\
Recurrence of active HCMV infection median time-days & $1 / 5(20)$ & $4 / 15(26.7)$ & $5 / 20(25)$ \\
(range) (AGM and N-PCR simultaneously positive) & 98 & $128(93-189)$ & $128(93-189)$ \\
\hline
\end{tabular}


Table 4. Relationship between AGM and N-PCR during follow-up of 33 patients after the transplant

\begin{tabular}{|c|c|c|c|c|}
\hline & $\begin{array}{c}\text { AGM/ } \\
\text { N-PCR } \\
\text { negative }\end{array}$ & $\begin{array}{c}\text { Only } \\
\text { N-PCR } \\
\text { positive }\end{array}$ & $\begin{array}{c}\text { N-PCR (+) } \\
\text { before AGM } \\
(+)\end{array}$ & $\begin{array}{c}\text { AGM and } \\
\text { N-PCR simultaneously } \\
\text { positive }\end{array}$ \\
\hline $\operatorname{RENAL}(\mathrm{n}=19)$ & $4(21 \%)$ & $2(10.5 \%)$ & $4(21 \%)$ & $9(47.4 \%)$ \\
\hline $\operatorname{BMT}(n=14)$ & $9(64.3 \%)$ & $2(10.5 \%)$ & $1(7 \%)$ & $2(14.3 \%)$ \\
\hline Total $(n=33)$ & $13(39.4 \%)$ & $4(12 \%)$ & $5(15 \%)$ & $11(33.3 \%)$ \\
\hline HCMVSymptoms & - & - & - & $9(81.8 \%)$ \\
\hline
\end{tabular}

\section{HCMV disease}

Nine out of twenty patients with active HCMV infection (45\%) developed presumptive HCMV disease. Two out of five $(40 \%)$ of these patients were bone marrow recipients and seven out of fifteen $(46.7 \%)$ were recipients of renal transplants, all of them received kidnies from a cadaveric donor. The most frequent symptoms in these patients were fever, diarrhea and vomiting. Patients with active HCMV infection, detected by
AGM and/or N-PCR plus clinical symptoms, were considered presumptive HCMV disease.

\section{Recurrence of HCMV disease}

Recurrence of HCMV disease occurred in five out of nine patients (55.5\%) with previous HCMV disease, in a median of 128 days after the transplant. These results are summarized in Table 5.

Table 5. Incidence of HCMV disease in patients with active HCMV infection.

\begin{tabular}{lccc}
\hline & BMT - n(\%) & Renal - n(\%) & Total - n (\%) \\
& $\mathbf{N = 1 4}$ & $\mathbf{N = 1 9}$ & $\mathbf{N = 3 3}$ \\
\hline Patients with active HCMV infection, n (\%) & $5(35.7)$ & $15(79)$ & $20(60.6)$ \\
median time-days (range) & $41(13-98)$ & $42(16-110)$ & $41(13-98)$ \\
HCMV Disease (\%) & $2(40 \%)$ & $7(46.7)$ & $9(45)$ \\
median time-days (range) & $41(41-42)$ & $49(31-72)$ & $42(31-72)$ \\
Recurrence of HCMV Disease or late HCMV disease & $1 / 2(50)$ & $4 / 7(57)$ & $5 / 9(55.5)$ \\
median time-days (range) & 98 & $110(98-198)$ & $128(98-198)$ \\
\hline
\end{tabular}

\section{Causes of death}

Four patients died (12.1\%). Three of these died as a result of the BMT $(21.4 \%)$. One death was the result of HCMV disease (interstitial pneumonia-IP), one was transplant-related and one due to other causes. The renal transplant recipient died due to graft-dysfunction.

\section{Relationship between AGM and N-PCR}

Table 4 shows the relationship between AGM and N-PCR during follow-up of 33 patients after transplant. Active HCMV infection detection occurred in 20 patients (60.6\%). In 4 patients (20\%), only the N-PCR detected active HCMV infection, but no patient had manifestation of disease.

\section{Analysis of gB variation by N-PCR-RFLP}

In the HCMV-DNA positive samples of twenty patients with active HCMV infection and five HCMV-DNA positive samples of patients with recurrence of active HCMV infection 
(total $=25)$, nested polymerase chain reaction amplification was performed, using primers for the $\mathrm{gB}$ region. Restriction enzyme digestion of the HCMV gene was performed and resulted in four digestion patterns, as previously demonstrated (9). The genotypes detected by PCR using primers gB1319 and gB1604 are presented in Table 6. Genotypes found were: Nine HCMVDNA positive samples (45\%) compatible with the $\mathrm{gB} 1$ genotype. Five (25\%) samples were compatible with gB2 and six patients were a mixture of $\mathrm{gB}$ genotypes. Coinfections with two different HCMV genotypes were frequently detected. Of the patients that demonstrated a mixture of gB types, $3(12 \%)$ were compatible with the $\mathrm{gB} 1$ and $\mathrm{gB} 2$, genotypes two were $\mathrm{gB} 1$ and $\mathrm{gB} 4(8 \%)$ and one was gB2 and $\mathrm{gB} 3(4 \%)$. No gB3 and gB4 genotypes were found alone in the patients studied; however, these genotypes were detected in gB mixtures.

\section{Prevalence of gB-HCMV subtypes and their correlation with clinical findings}

All patients that demonstrated the gB1 genotype had symptoms of the presumptive HCMV disease and were successfully treated with ganciclovir. All patients demonstrating the gB2 genotype presented more severe symptoms and HCMV reactivation after ganciclovir treatment. On the other hand, patients with a mixture of gB types did not demonstrate symptoms of HCMV disease and had a better prognostic.

Table 6 - Genotypes found in 25 HCMV-DNA positive samples and HCMV disease (active HCMV infection plus recurrence).

\begin{tabular}{|c|c|c|c|c|c|}
\hline $\begin{array}{l}\text { Distribution of } \\
\text { HCMV genotypes }\end{array}$ & & $\begin{array}{c}\text { BMT }-\mathrm{n}(\%) \\
\mathrm{N}=5\end{array}$ & $\begin{array}{c}\text { Renal - n (\%) } \\
\mathbf{N}=\mathbf{1 5}\end{array}$ & $\begin{array}{c}\text { Total }-\mathbf{n}(\%) \\
\mathbf{N}=\mathbf{2 0}\end{array}$ & $\begin{array}{c}\text { Patients with } \\
\text { Episodes of HCMV } \\
\text { Disease n }(\%)\end{array}$ \\
\hline $\begin{array}{l}\text { Glycoprotein type } 1 \\
\text { (gB1) }\end{array}$ & & $1(20)$ & $8(53.3)$ & $9(45)$ & $9(100)$ \\
\hline $\begin{array}{l}\text { Glycoprotein type } 2 \\
\text { (gB2) }\end{array}$ & & $1(20)$ & $4(26.7)$ & $5(40)$ & $5(100)$ \\
\hline $\begin{array}{l}\text { Glycoprotein type } \\
\text { (gB3) }\end{array}$ & 3 & - & - & - & - \\
\hline $\begin{array}{l}\text { Glycoprotein type } \\
\text { (gB4) }\end{array}$ & 4 & - & - & - & - \\
\hline Mixed gB1 + gB2 & & $1(20)$ & $2(13.3)$ & $3(15)$ & - \\
\hline Mixed gB1 + gB4 & & $1(20)$ & $1(6.7)$ & $2(10)$ & - \\
\hline Mixed gB2 $+\mathrm{gB} 3$ & & $1(20)$ & - & $1(5)$ & - \\
\hline
\end{tabular}

\section{DISCUSSION}

This study was performed in a group of children who underwent bone marrow or renal transplant and was the first to be performed in Brazil. HCMV is the most important cause of disease occurring after renal or bone marrow transplantation. In renal transplant patients, HCMV is associated with an increased risk of rejection and, in BMT, HCMV infection often causes severe morbidity and may even cause death, particularly during the first 3 months after allogeneic $\operatorname{SCT}(27,28)$. Specific studies on children are lacking, and the majority of data are derived from studies performed in adults (8). 
Several techniques are currently available for the early detection of CMV, including quantitative PCR, (16) the detection of mRNA (13) and a hybrid capture assay (20). These techniques have not yet been adequately compared to others that are currently available (26).

Two techniques for HCMV detection were used in this study, on a Nested PCR in leukocytes and antigenemia. Yaghobi et al, in 2005, showed the prognostic value of a double primer PCR assay to detect human cytomegalovirus (HCMV) infection or disease in bone marrow transplant (BMT) recipients (41). To discriminate between latent and active HCMV infection, blood samples were also tested by a quantitative antigenemia assay and compare with a double primer PCR assay and there was a good association between these tests for detection of active HCMV infection in all patients. Detection of HCMV-DNA in PMN leukocytes of BMT patients by double primer PCR assay can be an alternative method for antigenemia assay in leukopenic BMT recipients (41). In some of our cases, N-PCR detected active HCMV infection earlier than AGM, but in most of detections, AGM and N-PCR were detected simultaneously, according to our previous study (5).

Xue W et al, in 2009, evaluate the diagnostic value of CMV-PCR and CMV-pp65 antigenemia for active HCMV monitoring infection after renal transplantation. The sensitivity and specificity of these two combined detection methods for CMV infection were high for the diagnosis of CMV infection. CMV-pp65 and CMV-PCR combined together provide an effective method to monitor CMV infection and predict its outcome (40).

The incidence of active HCMV infection in our 33 children, with a median of 11- years old (range 2-18), was $60.6 \%$. Fourteen were allogeneic bone marrow transplant recipients and nineteen were renal transplant recipients.

Our results show that the incidence of HCMV infections in renal transplant recipients was $79 \%$ and HCMV disease was $46.7 \%$. This occurred within 2 months of transplantation. Rates of HCMV infection after renal transplant have been reportedly as high as $75 \%$ and the incidence of HCMV disease is between 5 and $30 \%(3)$.

In our study, the patients with HCMV disease were not proven. Proof of HCMV disease is difficult due to the need for more invasive methods. Nevertheless, the data from this hypothesis-generating study suggest transplant characteristics associated with HCMV disease that, in turn, can be targeted for further studies likely to yield feasible prevention strategies. In our study, the patients with presumptive HCMV disease were treated successfully.

The patients with active HCMV infections who were HCMV positive by Nested PCR had their DNA samples submitted to HCMV genotyping, according with publications $(2,9,10,12,33,36)$. The most frequently found genotypes were $\mathrm{gB} 1$ and $\mathrm{gB} 2$ (13). The genotypes $\mathrm{gB} 3$ and $\mathrm{gB} 4$ were found mixed with $\mathrm{gB} 1$ and $\mathrm{gB} 2$. The main clinical findings of presumptive HCMV disease in these patients were fewer, and occurred only in patients with the gB1 genotype. In patients with the gB2 genotype, the symptoms were more serious, such as diarrhea, abdominal pain and vomiting (presumptive HCMV gastrointestinal disease). With the mixture of genotypes, no symptoms occurred. This finding is in accordance with Woo et al., 1997 (39), who showed that HCMV gB type 2 is more frequent in BMT recipients with HCMV disease.

Zhou et al, in 2007 showed that genetic variability within the gB genes occurs frequently (43). In a previous study, in Canada (21), of 50 solid organ transplant recipients with CMV disease, the following distribution of $\mathrm{gB}$ was observed: $\mathrm{gB} 1$, 19/50 (38\%); gB2, 9/50 (18\%); gB3, 12/50 (24\%), gB4, 2/50 (4\%), and mixed genotype infection was $16 \%$.

The study done by Carraro and Granato, in 2003, demonstrated that the presence of several $\mathrm{gB}$ strains in any given patient is most likely not due to primary infection by several strains but is more likely due to consecutive new infections by strains of different $\mathrm{gB}(7)$.

Several risk factors for disease have been identified and include: HCMV-positive donors, HCMV-negative recipients, lack of anti-viral prophylaxis, and receipt of a cadaveric kidney 
$(27,42)$. Intense immunosuppression has also been implicated (42). Pediatric renal transplant recipients, by virtue of their age, are more likely to have a combination of donorpositive/recipient-negative grafts. They receive more immunosuppression and generally have a higher incidence of other viral infections.

The risk of development of HCMV disease was most strongly correlated with transplantation using a kidney from a HCMV-seropositive donor, particularly when the recipient was sero negative. This finding is consistent with two previous pediatric studies, which showed that transplantation from a HCMV-seropositive donor was strongly correlated with HCMV disease in the seronegative recipient $(22,27)$ and these findings also suggest that, in pediatric patients, primary infection due to transplants from donors with HCMV infection may be more important than the re-activation of already established infections related to intense imunossupression (16).

In conclusion, this study indicated that active HCMV infection detected by Nested-PCR and antigenemia together can be good methods for monitoring active HCMV infection and gB types 1 and 2 are more prevalent in our patients with HCMV disease. However, this study is limited because of the small patient number, thus making it difficult to draw a firm conclusion about the distribution of HCMV genotypes and their possible association with different types of patients and diseases. Nevertheless, these results may be taken as a preliminary report on the prevalence of different HCMV $\mathrm{gB}$ genotypes in Brazilian pediatric renal and bone marrow transplantation patients with active HCMV infection.

\section{REFERENCES}

1. Alberola, J.; Dominguez, V.; Cardeñoso, L.; López-Aldeguer, J.; Blanes, M.; Estellés, F.; Ricart, C.; Pastor, A.; Igual, R.; Navarro, D. (1998). Antibody Response to Human Cytomegalovirus (HCMV) Glycoprotein $\mathrm{B}(\mathrm{gB})$ in AIDS Patients with HCMV End-Organ Disease. J Med Virol; 55:272-80.

2. Albuquerque, D.M.; Costa, S.C.B. (2003). Genotyping of Human Cytomegalovirus using Non-Radioactive Single-Strand Conformation Polymorphism (SSCP) Analysis. J Virol Methods; 110:25-28.

3. Boeck, G.; Sollivan, K.; Miller, D. et al. (1997). Cytomegalovirus infections following renal transplantation- effects of antiviral prophylaxis: a report of North American Pediatric Renal Transplant Cooperative Study. Pediatr Nephrol; 11:665-71.

4. Bongarts, A.; von Laer, D.; Vogelberg, C.; Ebert, K.; van Lunzen, J.; Garweg, J.; Vaith, P.; Hufert, F.; Haller, O.; Meyer-Konig, U. (1996) Glycoprotein B Genotypes of Human Cytomegalovirus: distribution in HIV-Infected Patients. Scand J Infec Dis; 28: 447-49.

5. Bonon, S.H.A.; Menoni, S.M.F.; Rossi, C.L. et al. (2005). Surveillance of cytomegalovirus infection in haematopoietic stem cell transplantation patients. J Infect; 50:130-37.

6. Britt, W.J.; Mach, M. (1996). Human Cytomegalovirus Glycoproteins. Intervirology; 39(5, 6):401-12.

7. Carraro, E.; Granato, C.F. (2003). Single human cytomegalovirus gB genotype shed in multiple sites at the time of diagnosis in renal transplant recipients. J Med Virol. Jun;70(2):240-3

8. Castagnola, E.; Cappeli, B.; Erba, D.; Rabagliati, A.; Lanino, E.; Dini, G. (2004). Cytomegalovirus Infection after Bone marrow transplantation in children. Hum Immunol; 65:416-422.

9. Chou, S.; Dennison, K.M. (1991). Analysis of Interstrain Variation in Cytomegalovirus Glycoprotein B Sequences Encoding NeutralizationRelated Epitopes. J Infect Dis; 163:1229-234.

10. Chou, S. (1990). Newer Methods for Diagnosis of Cytomegalovirus Infection. Rev Infect Dis; 12(7):727-35.

11. Demmler, G.J.; Buffone, G.J.; Schimbor, C.M.; May, R.A. (1988). Detection of Cytomegalovirus in Urine from Newborns by Using Polymerase Chain Reaction DNA Amplification. J Infect Dis; 158:1177184.

12. Fries, B.C.; Chou, S.; Boeckh, M.; Torok-Storb, B. (1994). Frequency Distribution of Cytomegalovirus Envelope Glycoprotein Genotypes in Bone Marrow Transplant Recipients. J Infect Dis; 169:769-74.

13. Gerna, G.; Baldanti, F.; Lilleri, D. et al. (2000). Human cytomegalovirus immediate-early mRNA detection by nucleic acid sequence-based amplification as a new parameter for pre-emptive therapy in bone marrow transplant recipients. J Clin Microbiol 38, pp. 1845-1853.

14. Gondo, H.; Minematsu, T.; Harada, M. et al. (1994). Cytomegalovirus (CMV) antigenaemia for a rapid diagnosis and monitoring of CMVassociated disease after bone marrow transplantation. $\mathrm{Br} J$ Haematol; $1: 130-37$.

15. Goodrich, J.M.; Mori, M.; Gleaves, C.A. et al. (1991). Early treatment with Ganciclovir to prevent cytomegalovirus diseases after allogeneic bone marrow transplantation. N Engl J Med; 235(23):1601-07.

16. Gor, D.; Sabin, C.; Prentice, H.G. et al. (1998). Longitudinal fluctuations in cytomegalovirus load in bone marrow transplant patients: relationship between peak virus load, donor/recipient serostatus, acute GVHD and CMV disease. Bone Marrow Transplant 21, pp. 597-605.

17. Haastrup, E.; Müller, K.; Baekgaard, H.; Heilmann, C. (2005). Cytomegalovirus infection after allogeneic stem cell transplant in children. Pediatr Transplant; 9:734-40.

18. Halwachs, G.; Zach, R.; Pogglitsch, H.; Holzer, H. et al. (1993). A rapid immunocytochemical assay for CMV detection in peripheral blood of 
organ-transplanted patients in clinical practice. Transplantation; 56(2): 338-42.

19. Hebart, H.; Greif, M.; Krause, H.; Kanz, L.; Jahn, G.; Müller, C.A.; Einsele, H. (1997). Interstrain Variation of Immediate Early DNA Sequences and Glycoprotein B Genotypes in Cytomegalovirus Clinical Isolates. Med Microbiol Immunol; 186:135-38.

20. Hebart, H.; Wuchter, P.; Loccr, J. et al. (2001). Evaluation of the Murex CMV DNA hybrid capture assay version 2.0 for early diagnosis of cytomegalovirus infection in recipients of an allogeneic stem cell transplant. Bone Marrow Transplant 28 pp. 213-218.

21. Humar, A.; Kumar, D.; Gilber, C. et al. Cytomegalovirus (CMV) glycoprotein B genotype and response to antiviral therapy in solid organ transplant recipients with CMVdisease. J Infect Dis 2003; 188: 581-584.

22. Iragorri, S.; Pillayd, S.; Trompeterrs, R.L.; Griffiths, P.D. (1993). Prospective Cytomegalovirus Surveillance in Pediatric Renal Transplant Patients. Pediatr Nephrol; 7:55-60.

23. Kullberg-Lindh, C.; Ascher, H.; Krantz, M.; Lindh, M. (2003). Quantitative analysis of CMV DNA in children during the first year after liver transplantation. Pediatr Transplant; 7:296-301.

24. Lasry, S.; Dény, P.; Asselo, C.; Rauzy, M.; Boucher, J.; Guyot, C.; Leroux, M.C.; Wartowski, A.; Reinert, P.; Nicolas, J.C.I. (1996). Variations in the Cytomegalovirus (CMV) Glycoprotein B Gene Sequence among CMV-Infected Children Attending Six Day Care Centers. J Infect Dis; 174:606-09.

25. Ljungman, P.; Plotkin, S.A. (1995). Workshop on CMV Disease: Definitions, Clinical Severity Scores, and New Syndromes. Scand J Infect Dis Suppl; 99:87-89.

26. Ljungman, P. (2002). Prevention and treatment of viral infections in stem cell transplant recipients. Br J Haematol 118, pp. 44-57.

27. Meyers, J.D.; Flournoy, N.; Thomas, E.D. (1986). Risk factors for Cytomegalovirus Infection after Bone Marrow Transplantation. $J$ Infect Dis; 153:478-88.

28. Miller, W.; Flynn, P.; McCulbugh, J.; Balfour, H.H.Jr.; Goldman, A.; Haake, R. et al. (1986). Cytomegalovirus infection after bone marrow transplantation: an association with acute graft-vs-host disease. Blood; 67: 1162-167.

29. Pannuti, C.S.; Kallás, E.G.; Muccioli, C.; Roland, R.K.; Ferreira, E.C.; Bueno, M.H.S.; Canto, C.L.M.; Vilas Boas, L.S.; Belfort, R. (1996). Cytomegalovirus Antigenemia in Acquired Immunodeficiency Syndrome Patients with Untreated Cytomegalovirus Retinitis. Am J Ophthalmol; 22:847-52.

30. Robinson, L.G.; Hilinski, J.; Grahan, F.; Hymes, L.; Beck-Sague, C.M.; Hsia, J. et al. (2002). Predictors of Cytomegalovirus Disease among Pediatric Transplant Recipients within one year of Renal Transplantation. Pediatr Transplan; 6: 111-18.

31. Shibata, D.; Martin, W.J.; Appleman, M.D.; Causey, D.M.; Leedom, J.M.; Arnheim, N. (1988). Detection of Cytomegalovirus DNA in
Peripheral Blood of Patients Infected with Human Deficiency Virus. $J$ Infect Dis;158:1185-92.

32. Spano, L.C.; Ferreira, M.S.R.; Almeida, M.S.; Nascimento, J.P.; Leite, J.P.G. (2007). HCMV gB genotypes in cervical secretion and placenta tissues in the state of Espírito Santo, Southeastearn Brazil. Braz. J Microbiol 38: 424-429.

33. Torok-Storb, B.; Boeckh, M.; Hoy, C.; Leisenring, W.; Meyrson, D.; Gooley, T. (1997). Association of Specific Cytomegalovirus Genotypes with Death from Myelossuppression after Marrow Transplantation. Blood; 90(5):2097-102.

34. Van der Bij, W.; Schirm, J.; Torensma, R.J.; van Son, W.; Tegzess, A.M.; Hauw, T. (1988). The comparison between Viremia and Antigenemia for Detection of Cytomegalovirus in Blood. $J$ Clin Microbiol; 26(12):2531-35.

35. Vogelberg, C.; Meyer-Konig, U.; Hufert, F.T.; Kirste, G.; von Laer, D. (1996). Human Cytomegalovirus Glycoprotein B Genotypes in renal Transplant Recipients. J Med Virol; 50:31-34.

36. Wada, K.; Mizuno, S.; Kato, K.; Kamiya, T.; Ozawa, K. (1997). Cytomegalovirus Glycoprotein B Sequence Variation among Japanese Bone Marrow Transplant Recipients. Intervirology; 40:215-19.

37. Wingart, R.Z.; Brytting, M.; Linde, A.; Wahren, R.; Grillner, L. (1998). Sequence Variation within Tree Important Cytomegalovirus Gene Regions in Isolates from Four Different Patient Populations. J Clin Microbiol; 36(12):3662-69.

38. Winston, D.J.; Ho, G.; Bartoni, R.N.; Mond, C.; Ebeling, D.F.; Buhles, W.C.; Champlin, R.E. (1993). Ganciclovir prophylaxis of cytomegalovirus infection and disease in allogeneic bone marrow transplant recipients: results of a placebo-controlled, double-blind trial. Ann Intern Med; 118:179-84.

39. Woo, P.C.Y.; Lo, S.K.F.; Saiu, H.; Peiris, J.S.M.; Wong, S.S.Y. et al. (1997). Distinct Genotypic Distributions of Cytomegalovirus (CMV) Envelope Glycoprotein in Bone Marrow and Renal Transplant Recipients with CMV disease. Clin Diagn Lab Immunol; 4:515-518.

40. Xue, W.; Liu, H.; Yan, H.; Tian, P.; Ding, X.; Pan, X.; Feng, X.; Xiang, H.; Hou, J.; He, X. (2009). Methodology for monitoring cytomegalovirus infection after renal transplantation. Clin Chem Lab Med.; 47(2):177-81.

41. Yaghobi, R.; Behzad-Behbahani, A.; Sabahi, F.; Roustaee, M.H.; Alborzi, A.; Ramzi, M.; Nourani, H. (2005). Comparative analysis of a double primer PCR assay with plasma, leukocytes and antigenemia for diagnosis of active human cytomegalovirus infection in bone marrow transplant patients. Bone Marrow Transplant. 35(6):595-9.

42. Zaia, J. (1996). Prophylaxis and treatment of CMV infection in transplantation. In: Mills J, Volberding PA, Corey L, editors. Antiviral Chemotherapy. New York: Plenum Press p. 143-60.

43. Zhou, L.; Fan, J.; Zheng, S.S.; Ma, W.H. (2007). Genetic variation within the glycoprotein $\mathrm{B}$ and $\mathrm{H}$ genes of human cytomegalovirus in solid organ transplant recipients. Transpl Infect Dis. Mar; 9(1): 73-7. 